\title{
The information compliance indexes The illustrative case of income taxes
}

Ilídio Tomás Lopes

ISCTE - University Institute of Lisbon

ilidio.tomas.lopes@iscte.pt

\begin{abstract}
The adoption of IASB's standards has represented, in the European Union, an important effort of harmonization towards the financial reporting comprehensiveness, reliability, relevance and comparability. This paper seeks to highlight the importance of Information Compliance Indexes (ICI), based on the accounting standards, as a proxy for reporting quality awareness. This approach is evidenced through an illustrative example about disclosures on deferred taxes, as required by IAS 12 . This standard prescribes the accounting treatment for current taxes, deferred assets and liabilities. These issues are usually perceived by stakeholders as indicators of companies' continuity and potential future returns. Based on non-financial listed companies of Euronext Lisbon regulated market, with reference to the end of fiscal years 2008 and 2012, an information compliance index was performed, based on that accounting standard. Then, this index was regressed with a set of performance and control indicators. Evidences have provided several statistical significant insights, which corroborate the findings that information compliance and disclosure levels depend from several performance and control indicators.
\end{abstract}

Keywords: financial reporting, compliance index, income taxes, IAS 12, deferred taxes 


\section{Los índices de cumplimiento de información. El caso ilustrativo del Impuesto de Sociedades}

\section{Resumen}

La adopción de las normas del IASB ha representado, en la Unión Europea, un importante esfuerzo de armonización hacia la integración de los informes financieros, la confiabilidad, la relevancia y la comparabilidad. En este trabajo se pretende dar a conocer la importancia de los índices de cumplimiento de la información (ICI), con base en las normas contables, como un proxy para la presentación de informes útiles. Este enfoque se pone de manifiesto a través de un ejemplo ilustrativo acerca de las revelaciones sobre los impuestos diferidos, como requiere la NIC 12. Esta norma prescribe el tratamiento contable de los impuestos corrientes e impuestos por activos y pasivos diferidos. Estos problemas suelen ser percibidos por los interesados como indicadores de la continuidad de las empresas y los posibles rendimientos futuros. Sobre la base de las empresas no financieras cotizadas en el mercado regulado Euronext Lisboa, con referencia a finales de los años fiscales 2008 y 2012, se realizó un índice de cumplimiento de la información, sobre la base de la norma contable. Este índice integra una regresión con un conjunto de indicadores de desempeño y control. La evidencia empírica ha proporcionado importantes conocimientos estadísticos que corroboran los hallazgos de que los niveles de cumplimiento de la información y de divulgación dependen de varios indicadores de desempeño y control.

Palabras clave: información financiera, índice de cumplimiento, impuesto de sociedades, NIC 12, impuestos diferidos

\section{Introduction}

The last two decades have been marked by an increase in the efforts of international accounting harmonization. This regulatory convergence has been also extensible to individual and consolidated accounts, depending on whether the company is listed or not in a regulated market such as EURONEXT, NYSE, BM\&FBOVESPA, among others. Despite the substantive differentiation between national and international accounting standards, the financial reporting characteristics depend on the size (e.g. total assets, turnover, and number of employees) of the organization. Thus, all the accounting standards share the same conceptual genesis towards the information quality, in particular their utility to stakeholders.

Year 2005 represents, in the European Union (EU), a new era in creating financial reporting rules for a worldwide capital market. The adoption of IASB's standards 
acts as an important effort in the convergence and harmonization of measurement and recognition rules. As described in Epstein and Jermakowicz (2010), those convergence efforts must include a core set of standards towards a comprehensive basis of accounting and related financial reporting. Furthermore, those standards must be high quality, enabling investors (domestic or foreigners) and other stakeholders to analyze companies' performance meaningfully both across time periods and between companies, inside or outside certain activity sector. As a grant of financial reporting utility, those standards must be rigorously interpreted, and applied, otherwise comparability and transparency would not be satisfactorily achieved.

The effect of change to IASB's rules will vary from country to country and from company to company (Morais and Fialho, 2008; Guggiola, 2010; Iatridis, 2012). In fact, most of the European countries have traditionally developed rules oriented to tax and other regulatory purposes instead of preparing a financial reporting based on comprehensive and reliable information to be disclosed to other external stakeholders, such as investors, customers, suppliers, employees, etc. Thus, in the beginning of 2005, all EU companies that have securities listed on an EU exchange must prepare consolidated accounts in conformity with IASB's standards. Complementarily, all the EU states must permit those standards in the consolidated accounts of non-listed companies such as small enterprises or charities. International Financial Reporting Standards (IFRS) are also permitted in the annual non-consolidated accounts of all companies, however, with some exceptions. All the principles stated in those standards aim the convergence to a harmonized financial reporting, ensuring the information comprehensiveness, reliability, relevance and comparability. In a globalized market, stakeholders demand both for quantitative (recognition and measurement requirements) and qualitative (disclosure requirements) information disclosures. Qualitative information is becoming increasingly important as part of an integrated financial reporting, as also required by international accounting standards. In addition to the requirements arising from the accounting standards about disclosure, organizational performance is also founded on drivers of value that, due to the difficulties in their recognition and measurement, are not included in the traditional financial reporting. This is the case of an entire typology of intangibles whose importance to the financial and strategic positioning of the organization is recognized by management, but whose inclusion in the financial reporting is hampered. Apart from the financial statements content and objectives, qualitative and discriminative information is required towards an integrated and crossed business comprehensiveness. Despite the effects of international accounting harmonization on markets efficiency (Morais and Fialho, 2008; 
Guggiola, 2010; Iatridis, 2012), the quality of information disclosed to stakeholders is certainly a key driver towards the mitigation of economic systemic uncertainty and risk.

The evolution of financial markets in recent years has been marked by uncertainty and risk, also reinforced by the negative perspectives of global economic growth. We have observed multiple behaviors and trends by the various economic groups, causing a slowdown in the economic growth. Thus, the crisis in the Eurozone and its subsequent adjustment needs, in some European countries such as Portugal, Greece and Ireland, have resulted in a significant downturn in the economic growth as evidenced by a negative change in GDP (CMVM, 2014). In the context of sovereign debt crises, uncertainty and risk induce the stock markets to continuous adjustments towards the mitigation of any adverse volatility effects (Iatridis, 2012). Companies tend to increase the disclosure information flows as the way to reduce and mitigate that uncertainty and provide assurance to domestic and foreign stakeholders, concerning the quality and comprehensiveness of their financial reporting.

\section{Aims and objectives}

This research aims at the illustration of the information disclosure compliance indexes as key indicators for stakeholders. In this particular case, we analyzed IAS 12 to illustrate the use of an index that evidences the level of compliance of information disclosure. Based on that index, this paper also aims at the identification of variables that best fit with the dissemination level on income taxes. Evidences, applied for non-financial listed companies for the years 2008 and 2012, all of them integrating the Euronext Lisbon regulated market, constitute an overview about information disclosure and compliance, respectively four and eight years after the international accounting standards adoption in Portugal, as required by EU. This illustrative paper also aims to provide the academic and scientific communities with new insights and contribute to a global and integrated index construction, structured around IFRSs adoption.

\section{Background theories and concepts}

Information translates everything that can be digitized and used by stakeholders. Nowadays, it represents everything that can be converted into a set of bits and disseminated through multiple platforms. It is a symbolic representation of a set 
of events, objects, and streams which requires rules in its disclosure (Shapiro and Varian, 1999). It also integrates the chain of knowledge creation when data acquires meaning, when it flows inside or across organizations, through multiple structured or unstructured networks. Its dynamic transformation is dynamically subjected to the filters of contextualization, categorization, calculation, correction, and condensation as stated by Davenport and Prusak (1998). Hence, information is a message in itself and is vulnerable to all the noise that arose from the processes of communication.

Several authors, including Dretske (1983), argue that information is all that can produce knowledge while others see it as a message flow (Nonaka, 1994). This flow of information supports the commitment and beliefs between organizations and their stakeholders. Thus, knowledge and information disclosure to the entire company value system is embedded in the traditional theories such as agency theory (Spence and Zeckhouser, 1971; Fama, 1980; Demski, 1980; Basu et al., 1985; Eisenhardt, 1985; Mitnick, 1992; Kosnik, 1987; Fontrodona and Sison, 2006; Kulik, 2005), legitimacy theory (Dowling and Pfeffer, 1975; Guthrie et al., 2004), institutional theory (DiMaggio and Powell, 1983; Gray et al., 1996; Chapman et al., 2009), and contingency theory (Reid and Smith, 2000, Thomas, 1991), among others. Thus, those theories have explained the various factors that influence the information disclosure drivers. However, it is our understanding that the factors that determine the dissemination of information result from a symbiosis between the business complexity and stakeholders' needs. Each of them has its basis in the social contract established between the company and its stakeholders, creating internal mechanisms to respond to changes that occur in the environment.

The contingency theory assumes a theoretical perspective that contingencies such as size, uncertainty and risk, technology and environmental pressures affect the organization's development and operating processes. Thus, organizations cannot develop a standard framework to plan, organize and control their own activities. On the other hand, institutional theory considers that organizations should adapt to external expectations, so there are external pressures to implement appropriate practices to disseminate information. The fact that organizations tend to implement the same structures and practices along time as a response to social requirements is designated in the literature as institutional isomorphism (DiMaggio and Powell, 1983). The theory of legitimacy is based on the notion of the social contract between the reporting entity and the society in which it operates (Guthrie et al., 2004). The 
dissemination of information is one way to relieve social pressure and legitimate their organizational activities.

However, the information disclosure issue is strongly based on the relation between principal and agent, as drivers of agency theory social agreement. Broadly, this theory has been incorporated in multiple scientific fields, particularly in accounting (Demski, 1980), in economics (Spence and Zeckhouser, 1971), in marketing (Basu et al., 1985), in political science (Mitnick, 1992), in finance (Fama, 1980; Fontrodona and Sison, 2006), in behaviour and organizational culture (Eisenhardt, 1985; Kosnik, 1987; Kulik, 2005) and in sociology (White, 1985; Shapiro, 2005). The controversy over its usefulness, applicability and validity, remains valid even today. It was developed during the 60's and the early 70's of the twentieth century, by several economists, including Arrow (1971) and Wilson (1968). It translates the problem of attitude to risk either by individuals and/or by groups (Ross, 1973). The differentiation of objectives inherent to those parties that leads their attitude is also different. Those are relations between the principal and agent, metaphorically supported by a contract-oriented behaviour of parties who take different attitudes towards risk (Jensen and Meckling, 1976).

According to Eisenhardt (1989), the agency relationship arises between two or more parties in a designated agent, acting for the other, called the main field in a particular decision. Acting both parties in favour of their own interest, the principal conducts its action to minimize costs, the agent in order to minimize their action. According to Jensen and Meckling(1976), the agency costs correspond to the sum of the costs of monitoring by the principal (associated with the incentives of the agent and the monitoring process of their activity), expenses of the undertaking by the agent (associated with resources spent by the agent to compensate the principal for inappropriate actions) and residual losses (associated with the degree of divergence between the agent's decisions and the decisions that potentially maximize the well-being of principal).

The paradigm of the usefulness of information for decision-making is now one of the key issues in the designing process towards the information dissemination to their stakeholders. The profound changes that have occurred in the economies in general and in particular business models require information to be disclosed in a timely manner and meeting the expectations of its users. However, many are the factors that determine the type, timing and intensity with which this information is disseminated. 
Assuming that information and knowledge are a key resource driven by individuals, groups, and organizations, the intensity in the disclosure process influences management decisions and stakeholders' actions as a whole (Shackelford et al. 2011). Market volatility, as a result of economic globalization, however, associated with traditional business models, increases the urgency to produce useful information that can support multiple decisions on a timely and reliable basis. The accounting harmonization effort that we have experienced in the last decades, comply with the need of information quality. This is not merely a mechanism of standardization but fundamentally a mechanism to ensure the comparability of the information produced, in a scattered way, in the context of a globalized market. As a result of the unquestionable advances in the information and communication technologies, many users and agents are more experienced with regard to the usefulness of the information. Organizations develop increasingly sophisticated systems that provide the information on a time-based way (Moahamed et al., 2010). This revolution in the concepts of time and space is one of the leading brands of digital revolution that has marked the last two decades. So far, information is disseminated to stakeholders through multiple platforms, however, improvements are required regardless its structuring and comprehensiveness. This increase is also associated with the development of integrated management and control systems.

The sophistication of those systems, through a dynamic two-way relationship, is characterized by the integration of financial and non-financial information, but also from its predictive nature. Management control systems have acquired flexibility by enabling organizations to identify trends and warning signs which facilitate the implementation of emerging strategies. Characterized by their multiple languages, these systems integrate both internal and external information (quantitative and qualitative). Qualitative information is becoming increasingly important as part of the integrated financial reporting. Thus, this evidence can be found in the international accounting standards, especially in the topics related to the information disclosures requirements. Although it is mandatory to disclose the information required by accounting standards, there is still some resistance to its disclosure, which can be explained by the theories mentioned above.

The usefulness issue of the information management has a diffuse scope, based on multiple drivers: the type of information user, their information needs, the emerging pressure from the capital markets, the changes occurred in the environment in which organizations develop their activities and even regulatory requirements often resulting from political decisions. Indeed, we cannot link a particular theory 
to the entities and stakeholders' behaviours, regarding the dissemination of information. Those theories have specific determinants that embody the individual and collective behaviours. These behaviours derive from the symbiosis assumptions which are inherent to each particular theory.

In this context, we assume that companies have a certain level of resistance in the disclosure of their liabilities. Stakeholders usually associate those liabilities to short or long term financial risk which detracts companies to voluntarily disclose this type of information. Although those disclosures are mandatory according to international accounting standards, most of them do not comply with those requirements. This assumption supports the need to identify an "Information Compliance Index" (ICI) for the main liabilities recognised in the companies" financial statements, such as income taxes.

\section{Income taxes}

The issue of disclosure of the income taxes topics arises associated with the characteristic of the understandability of financial information. The breadth and clarity of accounting disclosure are highly dependent on the preparers of financial information. According to Meek et al. (1995), voluntary information only occurs in cases in which the benefits outweigh the costs. Although IAS 12 enumerates the requirements in terms of qualitative and quantitative extent of the topics to be disclosed, the content and form remain dependent on the discretion of the preparer of financial statements and related information.

That international standard, IAS 12, has the objective to prescribe the accounting treatment for income taxes. It requires that an entity account the tax consequences of transactions and other events in the same way that it occurs for the current transactions and other events. These effects are recognized only in the balance sheet (directly in equity) or in the balance sheet and in income statement. Thus, those recognitions can be perceived by stakeholders as indicators of company continuity and/or future expected returns (e.g., deferred assets).

Deferred taxes assets are the amounts of income taxes that are recoverable in future periods (deductible temporary differences, the carry forward of unused tax losses, and the carry forward of unused tax credits) while deferred taxes liabilities are the amounts of income taxes payable in future periods in respect to taxable temporary differences (IFRF, 2014). Hence, taxable temporary differences result in taxable 
amounts when the carrying amount of the asset or liability is recovered or settled. With regard to income taxes, IAS 12 establishes that, whenever applicable, company should disclose the following structured topics:

Table 1

\section{Main IAS 12 disclosure requirements}

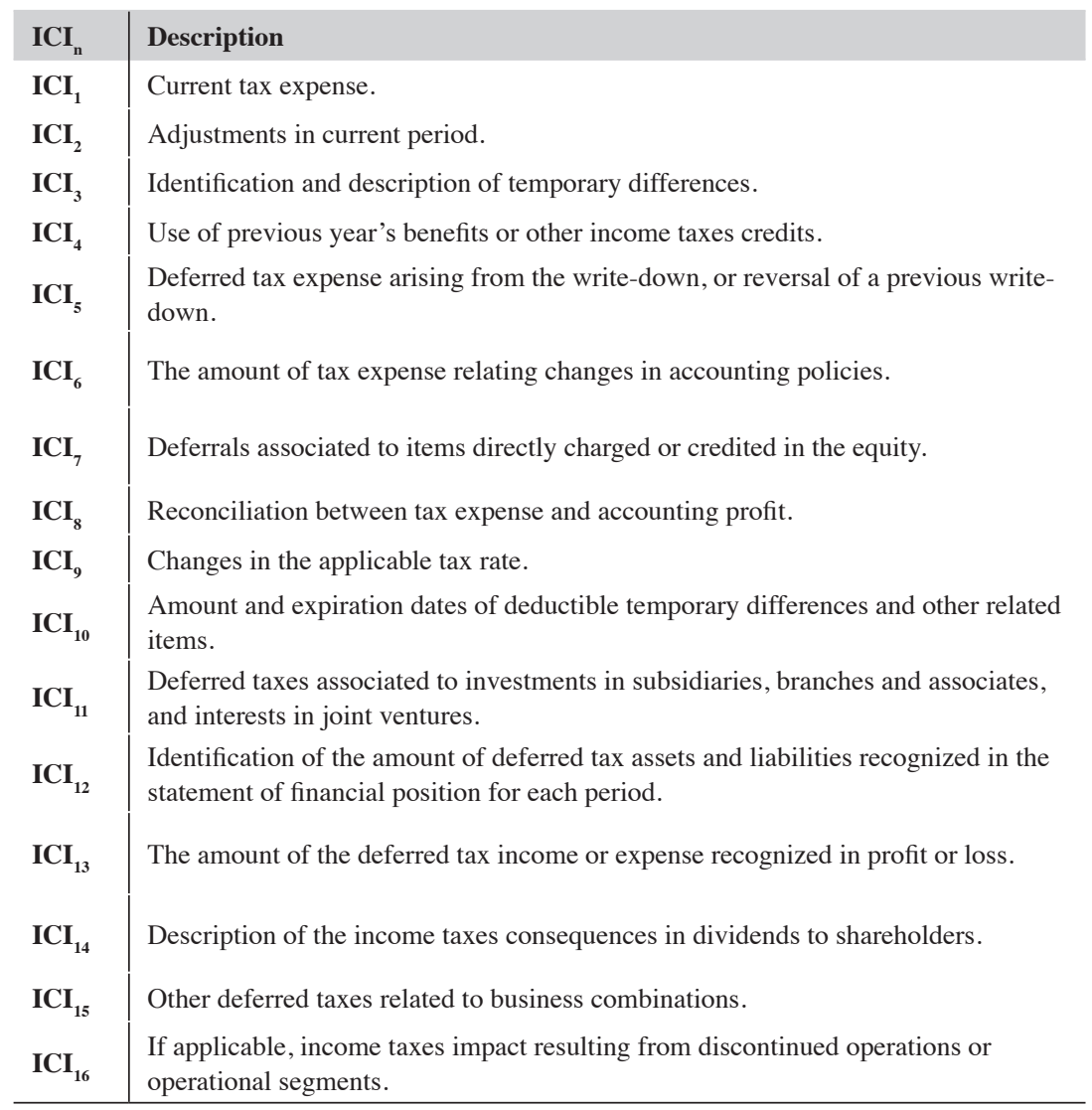

Source: Adapted from IAS 12 (IFRF, 2014).

We believe that those disclosure requirements are complex and, even in a holistic way, this may constitute a severe inhibitor to disclosure behavior. Thus, the financial reporting will be incomplete which implies a weak utility of the annual accounts and consequently the operations comprehensiveness and prediction level 
relating current and future returns. As evidenced by Amir et al. (1997), the omission of information relating income taxes are negatively associated with expected futures returns that flow to the entity. The omission of those effects undermines the completeness of financial information. To disclose information about deferred taxes is really relevant to stakeholders (Amir et al., 1997). Investors usually associate the disclosure of deferred taxes on revaluation of tangible and intangible assets with the expectation of continuous investments in depreciable and amortizable assets. Evidences obtained by Chaney and Jeter (1989) and by Colley et al. (2006) also show a positive association between deferred taxes recognition and company's capitalization. The market seems to recognize and incorporate the continuity of operations and their effects in terms of a desirable future returns.

\section{Information compliance indexes}

The construction of an Information Disclosure Index is a common technique to aggregate information in several scientific fields, especially in social sciences, and in particular in economics. In management and accounting, the same approach has been followed in order to identify the intensity and level of information compliance and reporting (Skinner, 1994; Wallace and Naser, 1995; Cooke, 1998; Bushee and Noe, 2000; Barako et al., 2006; Oliveira et al., 2006; Lopes and Rodrigues, 2007; Morais and Fialho, 2008; Al-Shammari et al., 2008; Guggiola, 2010; Mutawaaand Hewaidi, 2010; Broberg et al., 2010; Dragu and Tudor, 2011; Devalle and Rizatto, 2013). In this regard, Dragu and Tudor (2011) have regressed the disclosure index of borrowing costs (IAS 23) with multiple variables (e.g. turnover, return on assets, return on equity, total sales, debt rate, solvency) and have evidenced that an increase in debt rate would generate increased disclosure while an increase in solvency, in return on equity (ROE) and in return on assets (ROA), would mean lower quantities of disclosed information. Meanwhile, Mutawaaand Hewaidi (2010) found a negative association between leverage and disclosure compliance level (dependent variable). A positive and significant association was found between disclosure compliance level and company size, and sector of activity. These evidences corroborate the previous evidences provided by Wallace and Naser (1995), Oliveira et al. (2006), Lopes and Rodrigues (2007), Al Shammari et al. (2008), Iatridis (2012) and Devalle and Rizatto (2013). Type of auditing company (Big4) is also positively associated to the dependent variable, however not statistically significant. 
Lopes and Rodrigues (2007) have regressed the information disclosure requirements stated in IAS 32 and IAS 39 against company size, industry, auditor type, listing status, internationality, and other financial indicators such as debt/equity, market value/total assets, among others. The results support that larger firms, with higher leverage degree, also have a higher degree of information disclosure on financial instruments. However, empirical evidence does not support the type of industry, the type of auditor, the internationality degree, and the shareholder importance effects. Thus, the factors that most affect the level of compliance with IAS 32 and IAS 39 are the company size and its listing status. When the stepwise method was used within the multiple regression, the leverage variables were dropped. Complimentarily, Morais and Fialho (2008) have also confirmed that the level of compliance with IAS 39 requirements differs between the countries: UK companies present the highest index followed by Italian companies, French companies, and German companies. Thus, the harmonization process and standards compliance intensity is driven by economic factors, such as uncertainty and risk. In the context of sovereign debt crisis, characterized by intensity in uncertainty and risk, companies tend to intensify the information disclosures in order to mitigate any adverse volatility effects (Guggiola, 2010; Iatridis, 2012).

Concerning IFRS 3 (Business combinations) and IAS 36 (Impairments of assets), Devalle and Rizatto (2013) present an empirical analysis on the quality of the mandatory disclosure, namely the determinants that influence the quality of disclosure. Although we are facing mandatory information, evidences had provided that not all the groups disclosed the items required by those accounting standards. The variables that influence the compliance level are leverage, revenues, market values, and return on sales (ROS). Thus, the higher the market capitalization, leverage, revenues and ROS, the higher the attitude of companies to disclose mandatory information. Size and performance variables are not statistically significant in the context of mandatory information disclosures.

In the scope of voluntary information disclosures, Oliveira et al. (2007) have also identified the intangibles (IAS 38) that were reported by Portuguese listed companies in their annual reports. Results evidence a significant influence of size, ownership, auditing company, activity sector, and listing status. Complementarily, evidences also show that annual reports are still important vehicles for corporate managers to voluntarily disclose information. However, the hermetic boundaries of IAS 38 detract the disclosures in the areas of human capital, in comparison with relational or structural capital items. New developments are required towards the 
use of complementarily reports for intangibles as invisible drivers of value creation (Lev, 2001; Lopes, 2010).

Broadly, information disclosures are significantly associated to company size which means that large companies provide more mandatory and even voluntary disclosures than in SMEs (Wallace and Naser, 1995; Lopes and Rodrigues, 2007; Al-Shammari et al., 2008; Mutawaa and Hewaidi, 2010; Dragu and Tudor, 2011; Arvidsson, 2011; Iatridis, 2012). In relation to key profitability indicators such as ROE or ROA, evidences are not convergent (Wallace et al., 1994; Street and Gray, 2002; Al-Shammari et al., 2008; Broberg et al., 2010; Dragu and Tudor, 2011) which means that other variables exist that drive the effective information compliance and disclosure.

\section{Methodology}

\section{Data}

This research is based on 40 non-finance companies for the year 2008 and on 47 non-finance companies for the year 2012. Those companies were listed in the Euronext Lisbon regulated market, with reference to end of fiscal years 2008 and 2012, respectively. Financial data was collected from the Data Stream database and complementary information required for index construction was collected through the content analysis approach, based on companies' annual consolidated accounts. The process of data collection was based on the guidelines fixed in Abraham and Cox (2007).

\section{The theoretical index approach}

Information disclosure intensity can be evaluated through several approaches (Arvidsson, 2011), including the construction of a weighted or unweighted index metric (Oliveira et al., 2006; Lopes and Rodrigues, 2007; Mutawaaand Hewaidi, 2010; Oliveira et al., 2010; Dragu and Tudor, 2011; Devalle and Rizatto, 2013). The information compliance index (ICI) for each company can be achieved through the quotient between the total of items disclosed by each company and the sum of items that should be disclosed to stakeholders, according to the particular standard under analysis. The first step in this research consists in achieving the compliance disclosure index for income taxes, based on the content of IAS 12. Our unweighted index will be computed as follows: 


$$
I C I_{i}^{j}=\frac{\sum_{i=1}^{n} Y_{i}^{j}}{T D_{i}^{j}}
$$

Where:

$I C I_{i}^{j}$ - Disclosure index for IAS $_{\mathrm{j}}$ in company $\mathrm{i}$

$Y_{i}^{j}$ - Disclosure observed in company $\mathrm{i}$ for IAS $_{\mathrm{j}}$

$T D_{i}^{j}$ - Total disclosures required by $\mathrm{IAS}_{\mathrm{j}}$ and applicable to company $\mathrm{i}$

This index will be integrated in a multiple linear regression model as a dependent variable. This is an unweighted index which assums that all items are considered with the same level of importance to many users of financial statements. The use of weighting factors would imply a previous study of the importance attributed by many users of information, for each of the elements considered. Thus, the results would be eventually biased by subjective factors.

\section{Variables}

In the first step, we have looked for the construction of a disclosure index on income taxes (ICI). This index was included in the regression model as a dependent variable, illustrating the level of compliance about information disclosures, according to IAS 12 . Independent variables and corresponding signs are broadly supported by agency theory, legitimacy theory, contingency theory, and institutional theory (Demski, 1980; Dowling and Pfeffer, 1975; Thomas, 1991; DiMaggio and Powell, 1983, Reid and Smith, 2000; Guthrie et al., 2004; Chapman et al., 2009). The literature review also supports our assumptions and variables signs, in particular, Cooke (1998), Bushee and Noe (2000), Barako et al. (2006), Lopes and Rodrigues (2007), Dragu and Tudor (2011), Mutawaa and Hewaidi (2010), Broberg et al. (2010), and Oliveira et al. (2010). 
Table 2

Variables description and framework

\begin{tabular}{|c|c|c|c|}
\hline $\begin{array}{l}\text { VARIABLE } \\
\text { TYPOLOGY } \\
\end{array}$ & VAR. & DESCRIPTION & $\begin{array}{l}\text { PREDICTED } \\
\text { ECONOMIC SIGN }\end{array}$ \\
\hline DEPENDENT & ICI & Information compliance index for IAS 12 & \\
\hline \multirow{9}{*}{ INDEPENDENT } & DIM & Natural logarithm of total assets & + \\
\hline & ROA & $\begin{array}{l}\text { Return on assets (Net Income/Total } \\
\text { Assets) }\end{array}$ & $+/-$ \\
\hline & ROE & Return on equity (Net Income/Equity) & \\
\hline & EBITDA & $\begin{array}{l}\text { Natural logarithm of earnings before } \\
\text { interests, taxes, depreciation and } \\
\text { amortization }\end{array}$ & + \\
\hline & DEB & Debt ratio (Debts/Total Assets) & - \\
\hline & BGROW & $\begin{array}{l}\text { Business growth between } 2011 \text { and } 2012 \\
\text { and between } 2007 \text { and } 2008\end{array}$ & $?$ \\
\hline & NIGROW & $\begin{array}{l}\text { Net income growth between } 2011 \text { and } \\
2012 \text { and between } 2007 \text { and } 2008\end{array}$ & $?$ \\
\hline & AUDIT & $\begin{array}{l}\text { Auditing company ( } 1 \text { - Audited by a } \mathrm{Big}_{4} \\
\text { company and } 0 \text { otherwise) }\end{array}$ & + \\
\hline & SEC & Activity sector & \\
\hline
\end{tabular}

The dummy variable AUDIT assumes 1 if annual management report was certified by a Big 4 auditing company and 0 otherwise. Companies are aggregated in seven activity sectors as follows: 1 . Consumer services and transportation; 2. Equipment and industry; 3 . Construction and infrastructures; 4 . Technologies and communications; 5 . Consumer materials; 6 . Petrol and energy; and 7. Media and advertising.

\section{The predictive model}

In order to identify which variables $\left(\mathrm{X}_{\mathrm{i}} ; \mathrm{i}=1, \ldots k\right)$ best contribute to explain the variance of dependent variable, the model stated below has been regressed for the income taxes compliance index.

$$
\begin{aligned}
& \hat{I C I}=\beta_{0}+\beta_{1} D I M_{1 j}+\beta_{2} R O A_{2 j}+\beta_{3} R O E_{3 j}+\beta_{4} E B I T D A_{4 j} \\
& +\beta_{5} D E B_{5 j}+\beta_{6} B_{G R O W_{6 j}}+\beta_{7} \text { NIGROW }_{7 j}+\beta_{8} A_{U D D I T_{8 j}}+\beta_{9} S E C_{9 j}+\varepsilon \\
& (j=1, \ldots, n)
\end{aligned}
$$

Thus, all variables were simultaneously introduced in the model in order to identify which ones can predict (rejection of $\mathrm{H}_{0}: \beta_{1}=\beta_{2}=\ldots=\beta_{9}=0 ; \mathrm{p}<\alpha$ ) the infor- 
mation compliance index on income taxes, for non-finance listed companies, in 2008 and 2012.

\section{Results and discussion}

In 2012, the sector of consumer services and transportation integrates 11 companies (23.4\%) while the sector of basic equipment and industry represents $21.3 \%$ (10) of total companies. These two sectors represent, in $2008,55 \%$ of the total companies. The overall distribution by sector is evidenced in the graph below, for 2008 and 2012, respectively.

\section{Graph 1}

\section{Activity sectors (2008/2012)}

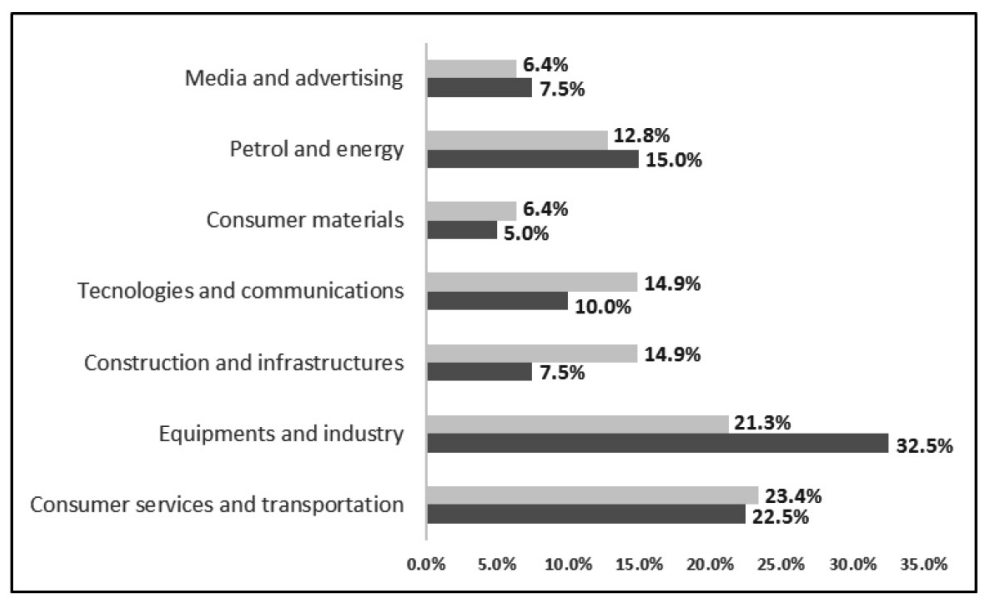

In order to provide an integrated overview about the variables included in the research, we summarize in table 3 the basic descriptive measures such as minimum, maximum, mean, and standard deviation. 
Table 3

Descriptive measures $(2008 / 2012)$

\begin{tabular}{c|c|c|c|c|c|c|c|c}
\hline \multirow{2}{*}{ VAR. } & \multicolumn{2}{|c|}{ Minimum } & \multicolumn{2}{c|}{ Maximum } & \multicolumn{2}{c|}{ Mean } & \multicolumn{2}{c}{ Std. Dev. } \\
\cline { 2 - 9 } & $\mathbf{2 0 0 8}$ & $\mathbf{2 0 1 2}$ & $\mathbf{2 0 0 8}$ & $\mathbf{2 0 1 2}$ & $\mathbf{2 0 0 8}$ & $\mathbf{2 0 1 2}$ & $\mathbf{2 0 0 8}$ & $\mathbf{2 0 1 2}$ \\
\hline ICI & 0.07 & 0.00 & 0.93 & 0.98 & 0.4574 & 0.5470 & 0.3282 & 0.29016 \\
\hline DIM & 6.9636 & 7.1432 & 10.2770 & 10.3192 & 8.7203 & 8.7398 & 0.7786 & 0.71919 \\
\hline ROA & -62.19 & -78.16 & 8.91 & 15.00 & -4.9728 & -1.6832 & 15.2425 & 13.3165 \\
\hline ROE & -586.61 & -190.87 & 20.23 & 56.10 & -26.4870 & -2.8264 & 101.7094 & 36.6475 \\
\hline EBITDA & 7.76228 & 5.64870 & 9.36780 & 9.1427 & 4.6821 & 7.3775 & 5.8840 & 0.88732 \\
\hline DEB & 43.46 & 27.93 & 305.02 & 533.85 & 87.9682 & 98.9568 & 51.1667 & 89.8898 \\
\hline BGROW & -53.86 & -52.60 & 87.29 & 16.22 & 8.7223 & -9.0311 & 30.5759 & 17.4445 \\
\hline NIGROW & -823.98 & -306.60 & 165.68 & 601.46 & -71.6570 & 38.8798 & 160.6501 & 145.9948 \\
\hline
\end{tabular}

The Information Compliance Index (ICI) on income taxes has improved approx. $20 \%$ between 2008 and 2012, as evidenced by variable mean ( 0.4574 and 0.5470 , respectively). However, the mean of business growth variable (BGROW) has decreased about $200 \%$. This evolution is probably related to the financial crises (including sovereign debts crises) which have started in the latest 2008. In fact, the last years were marked by uncertainty and risk, reflected in an economic downturn as a result of the recession in many European economies, including Portugal. The negative change in GDP has affected the stock market's volatility which has required companies the implementation of strategies towards the mitigation of negative effects (Iatridis, 2012; CMVM, 2014).The systemic risk of the financial system is strongly associated with the risk of the banking sector as a whole. Thus, the contagion with all companies, in particular companies driven by stock markets, has generally leveraged that systemic risk, currently affecting the companies' performance indicators.

In relation to auditing services, the companies' annual accounts were certified by a Big4 auditing company in $24(60 \%)$ cases, in the year 2008. In 2012, Big4 reinforce their position, certifying the annual accounts $72 \%$ of total cases. Complementarily, we found a positive and significant association between this variable and the information compliance index on income taxes for both years under analysis 
$\left(\chi^{2}=22.361 ; \mathrm{df}=13 ; \mathrm{p}=0.000\right.$ and $\chi^{2}=22.361 ; \mathrm{df}=13 ; \mathrm{p}=0.000$, respectively $)$. This evidence is consistent with the results achieved by Iatridis (2012) and Oliveira et al. (2006). Firms that are audited by a Big4 auditing company are likely to be more familiar with the requirements and content of IFRSs, and hence are able to provide a higher compliance level with accounting standards.

Table 4

Significant association measures

\begin{tabular}{c|c|c|c|c|c}
\hline Variable $\mathbf{X}_{\mathbf{n}}$ & Variable $\mathbf{X}_{\mathbf{p}}$ & $\chi^{2}$ & df & $\begin{array}{c}\text { Asymp. Sig. } \\
\text { (2-sided) }\end{array}$ & $\begin{array}{c}\text { Person's } \\
\text { Correlation }\end{array}$ \\
\hline $\mathrm{ICI}_{2008}$ & AUDIT & 22.361 & 13 & 0.048 & $\begin{array}{c}0.575^{*} \\
(0.000)\end{array}$ \\
\hline & ROA & 1253.33 & 1232 & 0.006 & $\begin{array}{c}0.403^{*} \\
(0.005) \\
0.360^{* *} \\
\mathrm{ICI}_{2012}\end{array}$ \\
& EBITDA & 1316.00 & 1288 & 0.013 & $\begin{array}{c}(0.013) \\
-0.431^{*} \\
(0.002) \\
0.474^{*} \\
(0.001)\end{array}$ \\
\hline
\end{tabular}

$*<0.01 * *<0.05 * * *<0.1$

Other significant associations were identified between ICI and other variables such as ROA, EBITDA, and DEB (table 4), even affected by economic systemic risk observed in the Portuguese economy during the period under analysis (CMVM, 2014). The persistence of the sovereign debt crisis in some European countries, including Portugal, has pressured the monetary devaluation, however, less intense in the last two years of the analyzed period. Although not statistically significant, DIM is positively associated with the index which corroborates the literature (Lopes and Rodrigues, 2007; Mutawaa and Hewaidi, 2010; Dragu and Tudor, 2011; Iatridis, 2012; Devalle and Rizatto, 2013). Broadly, larger companies tend to disclose higher levels of information, in accordance with IAS 12, in order to respond to the increase in the stakeholders information needs. This evidence is consistent with the results achieved by Oliveira et al. (2006), Lopes and Rodrigues (2007), and Devalle and Rizatto (2013), however, in the context of IAS 38, IAS 32 and IAS 39, and IFRS 3 and IAS 36, respectively. EBITDA, as a sustainability key performance indicator, is significantly associated with ICI only for the year 2012 $\left(\chi^{2}=1316.00 ; \mathrm{df}=1288 ; \mathrm{p}=0.013\right)$. This evidence is aligned with findings obtained by Devalle and Rizatto (2013), however, in the scope of IFRS 3 and IAS 36. 


\section{The regression model}

One of the main objectives in this research is to identify a set of variables that best explain the variance in the information disclosure level by the companies listed in the Euronext Lisbon. Furthermore, it also aims to provide the literature with additional insights in this scientific topic. Ordinary Least Squares (OLS) multiple regression were used to test the relationships between the various independent variables and control variable, and ICI. Outliers were removed from the analysis.

Table 5

Regression models summary

\begin{tabular}{|c|c|c|c|c|}
\hline \multirow{2}{*}{ VAR. } & \multicolumn{2}{|c|}{ ICI $_{2008}$} & \multicolumn{2}{|c|}{ ICI $_{2012}$} \\
\hline & $\beta$ & Sig. & $\boldsymbol{\beta}$ & Sig. \\
\hline (Constant) & -0.669 & 0.285 & -0.954 & $0.044^{* * *}$ \\
\hline DIM & 0.106 & 0.150 & 0.165 & 0.435 \\
\hline ROA & -0.008 & 0.143 & -0.089 & 0.652 \\
\hline ROE & 0.001 & $0.086^{* * * *}$ & -0.044 & 0.720 \\
\hline EBITDA & 0.003 & 0.813 & 0.278 & 0.195 \\
\hline DEB & -0.214 & 0.335 & -0.344 & $0.074^{* * * *}$ \\
\hline BGROW & 0.049 & 0.748 & 0.046 & 0.720 \\
\hline NIGROW & -0.125 & 0.590 & -0.357 & $0.003^{*}$ \\
\hline AUDIT & 0.368 & $0.001^{*}$ & 0.405 & $0.001^{*}$ \\
\hline SEC & 0.190 & 0.231 & 0.331 & $0.007^{*}$ \\
\hline & \multicolumn{2}{|c|}{$\mathrm{R}^{2}=0.534$} & \multicolumn{2}{|c|}{$\mathrm{R}^{2}=0.632$} \\
\hline & \multicolumn{2}{|c|}{$F=3.694$} & \multicolumn{2}{|c|}{$\mathrm{F}=6.437$} \\
\hline & \multicolumn{2}{|c|}{ Sig. 0.003* } & \multicolumn{2}{|c|}{ Sig. 0.000* } \\
\hline
\end{tabular}

$*<0.01 * *<0.05 * * *<0.1$

As expected, information disclosure on income taxes is positively correlated with company size (DIM), EBITDA, BGROW, AUDIT and sector of activity (SEC), however, not significantly. Audit company and activity sector evidences are consistent with evidences provided by Oliveira et al. (2006) and Lopes and Rodrigues (2007), both applicable to the Portuguese stock market, however, in our research not significantly correlated with company size. Otherwise, it is negatively correlated with ROA (p-value < 0.05), debt ratio and business growth rate, but it isonly significant for debt ratio. Corroborating the evidence provided by Dragu and Tudor (2011), an increase in debt rate (DEB), in return on equity (ROE) and in return on assets (ROA), it is associated to lower quantities of information disclosure and 
normative compliance. As already mentioned, this evidence can be associated with the economic systemic risk volatility (CMVM, 2014). A positive association was also found between disclosure compliance level and company size, and sector of activity. According to Iatridis (2012), firms would provide IFRS-related information in order to reduce uncertainty and give assurance to domestic and foreign stakeholders about the quality of their financial reporting. Furthermore, the sector of activity signs positively with the level of information compliance. Lower compliance indexes rates are observed in consumer services and transportation sector, and in basic equipment and industry activities.

The regression models are statistically significant for a $1 \%$ for 2008 and 2012 $\left(\mathrm{R}^{2}=0.534 ; \mathrm{F}=3.694\right.$; Sig.0.003 and $\mathrm{R}^{2}=0.632 ; \mathrm{F}=6.437$; Sig.0.000, respectively). Although several variables are not statistically significant, the regression equation for 2012 is evidenced towards an integrated predictive outlook.

$$
\begin{aligned}
& I C I=-0.954+0.165 D I M-0.089 R O A-0.044 R O E+0.278 E B I T D A \\
& -0.344 D E B+0.046 B G R O W-0.357 N I G R O W+0.4051 A U D I T+0.331 S E C
\end{aligned}
$$

The above equation can be used as a proxy to predict the compliance level of information disclosure on income taxes.

Most of the evidences achieved with current research corroborate other insights emerged from the literature review. However, the adoption of IFRSs is driven by multiple factors and affects the markets efficiency (Morais and Fialho, 2008; Guggiola, 2010; Iatridis, 2012). Hence, those evidences arise as new knowledge insights in the scope of financial information disclosure levels, particularly in the scope of IAS 12.

\section{Conclusions}

Several insights about information disclosure have been produced over the last decades. However, in globalized and volatile markets the topic relevance increases as a result of the businesses complexity and more decentralized stakeholders. Despite the complexity of the accounting harmonization process, strongly driven by markets uncertainty and risk, the compliance of information disclosure with international accounting standards is the most visible way to provide an outlook whether companies comply with their legal information disclosures obligations. Broadly, 
liabilities are potentially the most important inhibitor as far as stakeholders usually associate those liabilities to an overall risk level indicator. In the context of sovereign debts crises and inherent economic systemic risk, companies tend to manage their information disclosures in order to mitigate the market volatility effects.

Through a content analysis, an information compliance index on income taxes was computed for years 2008 and 2012. From an economically perspective, year 2008 points out the beginning of the sovereign debts crises in most European countries, including Portugal. The persistence of the sovereign debt crisis in some European countries, in particular in Portugal, has pressured the monetary devaluation in the last years, however, less intense since 2011 (CMVM, 2014). This intense volatility in stock markets has affected the companies' performance and consequently, the accounting harmonization process, in particular the flow of information disclosure. Thus, the information compliance index was subsequently regressed as the dependent variable with a set of independent variables such as size, profitability indicators, debt ratio, auditing, and activity sector. The models computed for both years are statistically significant, contrary to what occurs with some isolated variables. Positive associations were obtained between compliance indexes and some variables such as EBITDA, Return on Assets, Debt Ratio, Net Income Growth Rate, Auditing Company, and Activity Sector. Thus, the compliance level with IAS 12 is driven by financial and non-financial indicators. Extending the sample size, especially to other regulated markets (Morais and Fialho, 2008), could refine, on a reliable basis, those evidences and provide additional insights on the topic.

As further research, a disclosure index should be computed for a large range of time, in order to evaluate the trend in the intensity disclosure procedures. Thus, with years acting as a control variable, some economic effects could be observed and economically interpreted. Furthermore, specific detractors and enablers in the information disclosure behaviour can also be found if the analysis could be carried out for particular regions and countries.

\section{References}

Abraham, S. and P. Cox (2007). Analyzing the determinants of narrative risk information in UK FTSE 100 annual reports. The British Accounting Review 39 (3): $227-248$. 
Al Shammari, B., P. Brown and A. Tarca(2008). An investigation of compliance with international accounting standards by listed companies in the Gulf Co-Operation Council Member States. The International Journal of Accounting 43 (4): 425-447.

Amir, E., M. Kirschenheiter and K. Willard (1997). The Valuation of Deferred Taxes. Contemporary Accounting Research 14 (4): 597-622.

Arrow, K. (1971). Essays in the theory of risk bearing. Chicago: Markham.

Arvidsson, S. (2011). Disclosure of non-financial information in the annual reports. Journal of Intellectual Capital 12 (2): 277-300.

Ascioglu, A., S. P. Hedge and G. V. Krishnan (2012). Earnings management and market liquidity. Review of Quantitative Finance and Accounting 38: 257-274.

Basu, A., R. Lal, V. Srinivasan and R. Staelin (1985). Sales force compensation plans: An agency theoretic perspective. Marketing Science 4: 267-291.

Barako, D. G., P. Hancock and H.Y. Izan (2006). Factors influencing voluntary corporate disclosure by Kenyan companies. Corporate Governance: An International Review 14 (2): 107-125.

Bohusova, H. and D. Nerudova (2010). The Evaluation of the Convergence of US GAAP and IFRS in the Area of Borrowing Costs. The Business Review 16 (1): 300-305.

Boone, J. P., I. K. Khurana and K. K. Raman (2011). Litigation Risk and Abnormal Accruals. Auditing: A Journal of practice \& Theory 30 (2): 231-256.

Broberg, P., T. Tagesson and S. Collin (2010). What explains variation in voluntary disclosure? A study of the annual reports of corporations listed on the Stockholm Stock Exchange. Journal of Management and Governance 14: 351-377.

Bushee, B. J. and C. F. Noe (2000). Corporate disclosure practices, institutional investors, and stock return volatility. Journal of Accounting Research 38: 36-51. 
Chan, K., N. Jegadeesh and T. Sougiannis (2004). The Accrual Effect on Future Earnings. Review of Quantitative Finance and Accounting 22: 97-121.

Chaney, P. K. and D. C. Jeter (1989). Accounting for Deferred Income Taxes: Simplicity? Usefulness? Accounting Horizons 3 (2): 6-13.

Chapman, C., D. Cooper and P. Miller (2009). Linking Accounting, Organizations, and Institutions. In C. Chapman and P. Miller (eds.). Accounting Organizations and Institution. Oxford: University Press: 18-52.

Chou, D., M. Gombola and F. Liu (2010). Earnings management and long run performance following private equity placements. Review of Quantitative Finance and Accounting 34: 225-245.

Comissão de Mercado de Valores Mobiliários (2014). Relatório Anual 2012 sobre a Atividade da CMVM e sobre os Mercados de Valores Mobiliários. Available from http://www.cmvm.pt/cmvm/publicacoes/relatorios/relatorioanual2012/ Pages/Relat\%C3\%B3rioAnual2012.aspx

Colley, R., J. Rue and A. Volkan (2006). The Myth of Inter-Period Allocation of Deferred Taxes: Industry - Based Analyses. The Journal of American Academy of Business 8 (2): 1-8.

Cooke, T. E. (1998). Regression analysis in accounting disclosure studies. Accounting and Business Research 28 (3): 229-237.

Crawford, R. L. and T. R. Weirich (2011). Fraud guidance for corporate counsel reviewing financial statements and reports. Journal of Financial Crime 18 (4): $317-360$.

Cuzman, I., B. Dima and S. Dima (2010). IFRSs for financial instruments, quality of information disclosure and capital markets volatility: an empirical assessment for Eurozone. Accounting and Management Information Systems 9 (2): 284-304.

Davenport, T. H. and L. Prusak (2000). Working Knowledge: How Organizations Manage What They Know. Boston: HBSP. 
Demski, J. (1980). A simple case of indeterminate financial reporting. Working paper, Stanford University, Stanford, CA.

Devalle, A. and F. Rizatto (2013). IFRS 3, IAS 36 and Disclosure: The Determinants of the Quality of Disclosure. GSTF International Journal on Business Review (GBR) 2 (4): 12-17.

DiMaggio, P. and W. Powell (1983). The iron Cage Revisited: Institutional Isomorphism and Collective Rationality in organization fields. American Sociological Association 48:147-160.

Dowling, J. and J. Pfeffer (1975). Organizational Legitimacy: Social Values and Organizational Behaviour. Pacific Sociological Review 18 (1): 122-136.

Dragu, I. and A. T. Tudor (2011). Developing an econometric model for measuring the evolution of information disclosure - IAS 23 Borrowing costs. Annales Universitatis Apulensis Series Oeconimica 13 (2): 254-259.

Dretske, F. I. (1983). Knowledge \& the Flow of Information, Cambridge: the MIT Press.

Eisenhardt, K. M. (1985). Control: Organizational and economic approaches. Management Science 31: 134-149.

(1989). Agency theory: an assessment and review. Academy of Management Review 14 (1): 57-74.

Epstein, B. J. and E. K. Jermakowicz (2010). IFRS Interpretation and Application of International Financial Reporting Standards. Somerset: John Wiley \& Sons.

Fama, E. (1980). Agency problems and the theory of the firm. Journal of Political Economy 88: 288-307.

Fontrodona, J. and A. J. G. Sison (2006). The Nature of the Firm, Agency Theory and Shareholder Theory: A Critique from Philosophical Anthropology. Journal of Business Ethics 66: 33-42. 
Gray, R., D. Owen and C. Adams (1996). Accounting and accountability: Changes and challenges in corporate social and environmental reporting. London: Prentice-Hall.

Guggiola, G. (2010). IFRS Adoption in the E.U., Accounting Harmonization and Markets Efficiency: A Review. The International Business \& Economics Research Journal 9 (12): 99-112.

Guthrie, J., R. Petty, K. Yongvanich and F. Ricceri (2004). Using Content analysis as a Research Method to Inquire into Intellectual Capital Reporting. Journal of Intellectual Capital 5 (2): 282-293.

Holland, J. (2005). A grounded theory of corporate disclosure. Accounting and Business Research 35 (3): 249-267.

Iatridis, G. E. (2012). Voluntary IFRS disclosures: evidence from the transition from UK GAAP to IFRSs. Managerial Auditing Journal 27 (6): 573-597.

International Financial Reporting Foundation (2014). International Accounting Standard $N^{o} 12$. Available from http://www.ifrs.org/IFRSs/Pages/IFRS.aspx

Jensen, M. and W. Meckling (1976). Theory of the firm: managerial behaviour, agency costs, and ownership structure. Journal of Financial Economics 3: 305-360.

Lev, B. (2001) Intangibles: Management, Measurement, and Reporting. Washington: Brooking.

Lopes, I. T. (2010). Towards a complementary intangibles reporting approach. Measuring Business Excellence 14 (4): 24-34.

Lopes, P. T. and L. L. Rodrigues (2007). Accounting for financial instruments: an analysis of the determinants of disclosure in the Portuguese stock exchange. The International Journal of Accounting 42: 25-56.

Kosnik, R. (1987). Greenmail: A study in board performance in corporate governance. Administrative Science Quarterly 32: 163-185. 
Kulik, B. W. (2005). Agency Theory, Reasoning and Culture at Enron: In search of a Solution. Journal of Business Ethics 59: 347-360.

Marciukaityte, D. and S. H. Szewczyk (2011). Financing Decisions and Discretionary Accruals: managerial manipulation or managerial over optimism. Review of Behavioural Finance 3: 91-114.

Meek, G. K., C. B. Roberts and S. J. Gray (1995). Factors influencing voluntary annual report disclosures by U.S., U.K. and continental European multinational corporations. Journal of International Business Studies 26 (55): 555572.

Mitnick, B. (1992). The theory of agency and organizational analysis. University of Pittsburgh. In N. E. Bowie and E. Freeman (eds.). Ethics and Agency Theory: An Introduction, New York: Oxford University Press.

Moahamed, M., A. Murray and M. Mohamed (2010). The role of information and communication technology (ICT) in mobilization of sustainable development knowledge: a quantitative evaluation. Journal of Knowledge Management 14 (5): 744-758.

Morais, A. I. and A. Fialho (2008). Do Harmonised Accounting Standards Lead to harmonised Accounting Practices? An Empirical Study of IAS 39 Measurement Requirements in Some European Union Countries. Australian Accounting Review 18 (3): 224-236.

Mutawaa, A. and A. Hewaidy (2010). Disclosure Level and Compliance with IFRSs: An empirical investigation of Kuwaiti companies. The International Business \& Economics Research Journal 9 (5): 33-49.

Nonaka, I. (1994). A Dynamic Theory of Organizational Knowledge Creation, Organization Science 5 (1): 14-37.

Oliveira, L., L. Rodrigues and R. Craig (2006). Firm-specific determinants of intangibles reporting: evidence from the Portuguese stock market. Journal of Human Resource Costing \& Accounting 10 (1): 11-33. 
, L. Rodrigues and R. Craig (2011). Risk-related disclosures by non-finance companies: Portuguese practices and disclosure characteristics. Managerial Auditing Journal 26 (9): 817-839.

Reid, G. and J. Smith (2000). The Impact of Contingencies on Management Accounting System Development. Management Accounting Research 8: 147164.

Ross, S. (1973). The economic theory of agency: The principal's problem. American Economic Review 63: 13-139.

Shackelford, D. A., J. Slemrod and J. M. Salle (2011). Financial Reporting, tax, and real decisions: toward a unifying framework. International Tax Public Finance 18: 461-494.

Shaikh, A. M., M. J. Iqbal and S. Z. A. Shah (2012). Institutional ownership and discretionary Accruals: Empirical Evidences from Pakistani Listed Non-Financial Companies. Information Management and Business Review 4 (3): 217-222.

Shapiro, S. P. (2005). Agency Theory. Annual Review of Sociology 31: 263-284.

Shapiro, C. and H. R. Varian (1999). Information Rules: A Strategic Guide to the Network Economy. Boston: Harvard Business School Press.

Skinner, D. J. (1994). Why firms voluntarily disclose bad news. Journal of Accounting Research 32 (4): 38-60.

Spence, A. M. and R. Zeckhauser (1971). Insurance, information, and individual action. American Economic Review 61: 380-387.

Street, D. L. and S. J. Gray (2002). Factors influencing the extent of corporate compliance with international accounting standards: summary of a research monograph. Journal of International Accounting, Auditing and Taxation 11: $51-76$.

Thomas, A. (1991). Towards a Contingency Theory of Corporate Financial Reporting System. Accounting, Auditing \& Accountability Journal 4 (4): 40-57. 
Tiwana, A. (2002). The knowledge Management Toolkit: Orchestring IT, Strategy, and Knowledge Platforms, $2^{\text {nd }}$ edition. New Jersey: Prentice Hall.

Verecchia, R. E. (2000). Discretionary disclosure. Journal of Accounting and Economics 5: 179-194.

Wallace, R. S., K. Naser and A. Mora (1994). The relationship between the comprehensiveness of corporate annual reports and firm characteristics in Spain. Accounting and Business Research 25 (97): 41-53.

and K. Naser (1995). Firm-specific determinants of the comprehensiveness of mandatory disclosure in the corporate annual reports and firms listed on the stock exchange of Hong Kong. Journal of Accounting and Public Policy 14 (4): 311-368.

Watson, A., P. Shrives and C. Martson (2002). Voluntary disclosure of accounting ratios in the UK. British Accounting Review 34: 289-313.

Wilson, R. (1968). On the theory of syndicates. Econométrica 36: 119-132.

White, H. (1985). Agency as control. In J. Pratt and R. Zeckhaouser (eds.). Principles and agents: The structure of business. Boston: Harvard Business School Press: 187-214. (A) 
